\title{
PENGARUH SISTEM OLAH TANAH DANPEMUPUKAN NITROGEN JANGKA PANJANG TERHADAP AIR TERSEDIA DAN BEBERAPA SIFAT FISIK TANAH PADA PERTANAMAN PADI GOGO (Oryza sativa L.) DI LAHAN POLINELA BANDAR LAMPUNG
}

\author{
Reza Prasetia, Muhajir Utomo, Afandi \& Irwan Sukri Banuwa \\ Jurusan Agroteknologi, Fakultas Pertanian, Universitas Lampung \\ J1. Prof. Soemantri Brojonegoro, No. 1 Bandar Lampung 35145 \\ Email: rezaprasetia96@gmail.com
}

\begin{abstract}
ABSTRAK
Olah tanah konservasi (olah tanah minimum dan tanpa olah tanah) menjadi alternatif penyiapan lahan yang dilaporkan dapat mempertahankan produktivitas tanah tetap tinggi. Salah satu faktor penting yang menentukan keberhasilan olah tanah konservasi adalah dengan mengembalikan residu tanaman setelah panen sebagai sumber bahan organik dalam bentuk mulsa yang mampu menjaga sifat fisik tanah. Di sisi lain pengolahan yang intensif dapat merusak struktur dan ruang pori yang telah terbentuk dari bahan organik. Oleh karena itu, pengolahan tanah sebaiknya dilakukan seminimum mungkin. Tujuan penelitian ini adalah untuk mengetahui pengaruh sistem olah tanah dan pemupukan nitrogen jangka panjang terhadap air tersedia dan beberapa sifat-sifat fisik tanah seperti kerapatan isi, ruang pori total, dan tekstur tanah pada pertanaman padi gogo. Penelitian dilakukan dengan menggunakan Rancangan Acak Kelompok (RAK). Perlakuan disusun secara faktorial dengan 4 ulangan. Faktor pertama adalah pemupukan nitrogen terdiri dari pemupukan $0 \mathrm{~kg} \mathrm{~N} \mathrm{ha}^{-1}, 100 \mathrm{~kg} \mathrm{~N} \mathrm{ha}^{-1}$. Faktor kedua adalah sistem olah tanah terdiri dari tanpa olah tanah, olah tanah minimum, olah tanah intensif. Data yang diperoleh diuji homogenitasnya dengan uji Bartlet dan aditivitasnya dengan uji Tukey, kemudian dilakukan analisis ragam. Perbandingan nilai tengah pengamatan menggunakan uji BNT pada taraf 5\%. Hasil penelitian menunjukkan bahwa pada sistem olah tanah, kerapatan isi,

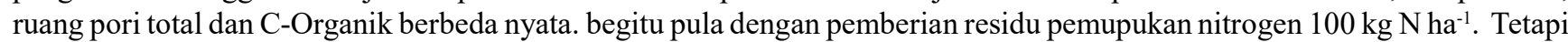
tidak terdapat interaksi antara sistem pengolahan tanah dan residu pemupukan $\mathrm{N}$ terhadap air tersedia, kerapatan isi, ruang pori total dan C-organik tanah.
\end{abstract}

Kata kunci: Padi gogo, residu pemupukan nitrogen, sistem olah tanah

\section{PENDAHULUAN}

Padi (Oryza sativa L.) merupakan komoditas pangan yang paling penting di Tropika Asia, terutama di Indonesia. Peningkatan jumlah penduduk menyebabkan permintaan beras semakin meningkat.Peningkatan produksi beras tidak hanya diandalkan dari lahan sawah irigasi dan tadah hujan, tetapi juga pada lahan kering (padi gogo).

Lahan kering merupakan salah satu sumber daya alam yang berpotensi untuk meningkatkan produksi pertanian di Indonesia. Akan tetapi, potensi tersebut belum dimanfaatkan secara optimal. Kendala-kendala yang sering ditemui pada lahan kering diantaranya adalah tingkat kesuburan tanah yang rendah, erosi yang tinggi dan kekeringan di musim kemarau. Untuk memberdayakan tanah tersebut secara maksimum perlu teknik budidaya yang cocok dalam pemecahan masalah penggunaan lahan kering untuk tanaman semusim. Olah tanah konservasi (OTK) merupakan salah satu pendekatan sistem produksi tanaman yang memperhatikan konservasi lahan (Utomo, 1989).

Selain dengan sistem olah tanah konservasi, usaha untuk meningkatkan produksi tanaman pangan juga dapat dilakukan dengan pemupukan. Pemupukan merupakan suatu tindakan pemberian unsur hara ke tanah atau tanaman sesuai yang di butuhkan untuk pertumbuhan normal tanaman (Pulung, 2005).

Penelitian ini bertujuan untuk mengetahui pengaruh sistem olah tanah terhadap air tersedia dalam tanah pada pertanaman padi gogo (Oryza sativa L.), mengetahui pengaruh pemupukan nitrogen jangka panjang terhadap air tersedia dalam tanah pada pertanaman padi gogo (Oryza sativa L.), dan mengetahui pengaruh interaksi antara sistem olah tanah dan pemupukan nitrogen jangka panjang terhadap air tersedia dalam tanah pada pertanaman padi gogo (Oryza sativa L.). 


\section{BAHAN DAN METODE}

Penelitian dilakukan di lahan Politeknik Negeri Lampung pada bulan November 2014 - Maret 2015. Penerapan olah tanah dilakukan dengan konservasi dan perlakuan pemupukan $\mathrm{N}$ jangka panjang dari tahun 1987 sampai dengan 2015. Analisis tanah dilakukan di Laboratorium Jurusan Ilmu Tanah Fakultas Pertanian Universitas Lampung.

Penelitian ini dirancang dalam rancangan acak kelompok (RAK) dan disusun secara faktorial dengan 4 ulangan. Faktor pertama adalah pemupukan nitrogen (N) yaitu $\mathrm{N}_{0}=0 \mathrm{~kg} \mathrm{~N} \mathrm{ha}^{-1}, \mathrm{~N}_{2}=100 \mathrm{~kg} \mathrm{~N} \mathrm{ha}^{-1}$, dan faktor kedua adalah perlakuan sistem olah tanah (T) yaitu $T_{1}=$ tanah diolah intensif dan $T_{2}=$ tanah diolah secara minimum dengan mulsa gulma dan jagung (tanaman sebelumnya), $\mathrm{T}_{3}=$ tanpa olah tanah dengan mulsa gulma dan jagung (tanaman sebelumnya). Data yang diperoleh diuji homogenitasnya dengan uji Barlet dan aditifitasnya dengan Uji Tukey. Jika asumsi terpenuhi data dianalisis dengan sidik ragam, perbedaan nilai tengah perlakuan diuji dengan uji Beda Nyata Terkecil (BNT) pada taraf 5\%.

Pada penelitian ini menggunakan tiga sistem olah tanah, yakni tanpa olah tanah, olah tanah minimum, dan olah tanah intensif. Pada saat 2 minggu sebelum tanam lahan disemprot menggunakan herbisida dengan dosis 3 liter ha ${ }^{-1}$, kemudian gulma tersebut digunakan sebagai mulsa pada petak tanpa olah tanah (TOT) ditambah dengan sisa tanaman jagung. Pada petak olah tanah minimum (OTM) tanah dicangkul dangkal dan gulma digunakan sebagai mulsa, dan pada olah tanah intensif (OTI) tanah dicangkul dua kali hingga kedalaman 20 $\mathrm{cm}$ dan sisa tanaman gulma dibuang dari petak percobaan.

Penanaman benih padi gogo varietas Inpago 8 dengan cara membuat lubang tanam dengan jarak 20 $\mathrm{cm} \times 25 \mathrm{~cm}$. Dosis pupuk urea yakni dosis $0 \mathrm{~kg} \mathrm{~N} \mathrm{ha}^{-1}$, $50 \mathrm{~kg} \mathrm{~N}^{-1}$, dan $100 \mathrm{~kg} \mathrm{~N} \mathrm{ha}^{-1}$, sedangkan dosis pupuk TSP yakni $100 \mathrm{~kg} \mathrm{ha}^{-1}$ dan $\mathrm{KCl} 50 \mathrm{~kg} \mathrm{ha}^{-1}$. Pemupukan Urea dilakukan secara 2 tahap, tahap pertama bersamaan dengan TSP dan $\mathrm{KCl}$ (1 minggu setelah tanam sebanyak $1 / 3$ dari total pupuk) sedangkan $2 / 3$ nya saat vegetatif maksimum. Variabel yang diamati meliputi kerapatan isi, ruang pori total, kadar air tanah kapasitas lapang, kadar air tanah titik layu permanen, air tersedia, C - organik, dan tekstur tanah.

\section{HASIL DAN PEMBAHASAN}

Hasil Penelitian. Hasil pengamatan menunjukkan bahwa Sistem olah tanah (T) nyata mempengaruhi kadar air tanahpada titik layu permanen dan air tersedia pada kedalaman tanah $20-40 \mathrm{~cm}$. Pemupukan nitrogen jangka panjang $(\mathrm{N})$ mempengaruhi kerapatan isi dan ruang pori total pada kedalaman 0 20 serta 20 - 40 (Tabel 1). Pemupukan nitrogen jangka panjang dan sistem olah tanah tidak mempengaruhi kadar air tanah kapasitas lapang baik pada kedalaman $0-20$ cm maupun $20-40 \mathrm{~cm}$ serta tidak mempengaruhi kadar

Tabel 1. Rekapitulasi hasil analisis ragam system pemupukan nitrogen jangka panjang dan sistem olah tanah pada kedalaman 0 - 20 dan 20 - 40 pada pertanaman padi gogo setelah panen

\begin{tabular}{lllll}
\hline \multirow{2}{*}{ Variabel Pengamatan } & Kedalaman & \multicolumn{3}{c}{ Signifikasi } \\
\cline { 4 - 5 } & Tanah $(\mathrm{cm})$ & $\mathrm{T}$ & $\mathrm{N}$ & $\mathrm{T} \mathrm{x} \mathrm{N}$ \\
\hline Kerapatan Isi (Bulk Density) & $0-20$ & $*$ & $*$ & tn \\
& $20-40$ & $*$ & $*$ & tn \\
Ruang Pori Total & $0-20$ & $*$ & $*$ & tn \\
Kadar Air Tanah Kapasitas Lapang & $20-40$ & $*$ & $*$ & tn \\
Kadar Air Tanah Titik Layu Permanen & $0-20$ & tn & tn & tn \\
& $20-40$ & tn & tn & tn \\
Air Tersedia & $20-40$ & $*$ & tn & tn \\
C - Organik & $0-20$ & tn & tn & tn \\
Ketn & $20-40$ & $*$ & tn & tn \\
& $0-20$ & $*$ & $*$ & tn \\
\hline
\end{tabular}

Keterangan: $*$ = berpengaruh nyata, $\mathrm{tn}=$ tidak berpengaruh nyata pada taraf $5 \%$ 
air tanah titik layu permanen dan air tersedia pada kedalaman 20 - $40 \mathrm{~cm}$ (Tabel 1). Selain itu, tidak terjadi interaksi antara pemupukan nitrogen jangka panjang $\mathrm{x}$ sistem olah tanah jangkapanjangpada seluruh variabel pengamatan baik pada kedalaman $0-20 \mathrm{~cm}$ maupun 20 - $40 \mathrm{~cm}$ (Tabel 1).

Kerapatan Isi. Sistem olah tanah mempengaruhi kerapatan isi (bulk density) baik pada kedalaman 0 $20 \mathrm{~cm}$ maupun $20-40 \mathrm{~cm}$ (Tabel 1). Pengaruh sistem olah tanah tersebut menyebabkan terjadi perbedaan kerapatan isi baik pada kedalaman $0-20 \mathrm{~cm}$ maupun kedalaman $20-40 \mathrm{~cm}$ (Tabel 2). Sistem olah tanah dengan tanpa olah tanah menunjukkan hasil yang lebih rendah dibandingkan dengan sistem olah tanah lainnya baik pada kedalaman $0-20 \mathrm{~cm}$ maupun $20-40 \mathrm{~cm}$ terhadap kerapatan isi (bulk density).

Kerapatan isi juga dipengaruhi oleh pemupukan nitrogen jangka panjang dan sistem olah tanah baik pada kedalaman 0 - $20 \mathrm{~cm}$ maupun kedalaman $20-40 \mathrm{~cm}$ (Tabel 1). Tetapi, tidak terjadi interaksi antara pemupukan nitrogen jangka panjang $\mathrm{x}$ sistem olah tanah terhadap kerapatan isi baik pada kedalaman $0-20 \mathrm{~cm}$ maupun $20-40 \mathrm{~cm}$. Pengaruh pemupukan tersebut menyebabkan terjadi perbedaan kerapatan isi baik pada kedalaman 0 - $20 \mathrm{~cm}$ maupun kedalaman 20 - $40 \mathrm{~cm}$ (Tabel 3). Pemupukan nitrogen jangka panjang dengan dosis $100 \mathrm{kgha}^{-1}$ memiliki kerapatan isi yang lebih rendah jika dibandingkan dengan tanpa pemupukan atau dosis pupuk $0 \mathrm{~kg} \mathrm{ha}^{-1}$ baik pada kedalaman $0-20 \mathrm{~cm}$ maupun $20-40 \mathrm{~cm}$.

Ruang Pori Total. Hasil penelitian menunjukkan bahwa ruang pori total dipengaruhi oleh Sistem olah tanah baik pada kedalaman 0 - $20 \mathrm{~cm}$ maupun 20 - 40 $\mathrm{cm}$ (Tabel 1). Pengaruh sistem olah tanah tersebut menyebabkan terjadi perbedaan ruang pori total baik pada kedalaman 0 - $20 \mathrm{~cm}$ maupun kedalaman 20 - 40 $\mathrm{cm}$ (Tabel 4). Sistem olah tanah dengan tanpa olah tanah menunjukkan hasil yang lebih tinggi dibandingkan dengan sistem olah tanah lainnya baik pada kedalaman 0 - 20 $\mathrm{cm}$ maupun $20-40 \mathrm{~cm}$ terhadap ruang pori total.

Pemupukan nitrogen jangka panjang dan sistem olah tanah jugamempengaruhiruangpori total baik pada kedalaman 0 - $20 \mathrm{~cm}$ maupun kedalaman $20-40 \mathrm{~cm}$ (Tabel 4). Selain itu, tidak terjadi interaksi antara pemupukan nitrogen jangka panjang $\mathrm{x}$ sistem olah tanah terhadap ruang pori total baik pada kedalaman 0 - 20 $\mathrm{cm}$ maupun $20-40 \mathrm{~cm}$. Pengaruh pemupukan tersebut menyebabkan terjadi perbedaan ruang pori total baik

Tabel 2. Pengaruh sistem olah tanah jangka panjang terhadap terhadap kerapatan isi kedalaman $0-20 \mathrm{~cm}$ dan $20-40 \mathrm{~cm}$ pada pertanaman padi gogo setelah panen.

\begin{tabular}{lcc}
\hline \multirow{2}{*}{ Sistem Olah Tanah } & \multicolumn{2}{c}{ Kerapatan isi $\left(\mathrm{g} \mathrm{cc}^{-1}\right)$} \\
\cline { 2 - 3 } & Kedalaman $0-20 \mathrm{~cm}$ & Kedalaman $20-40 \mathrm{~cm}$ \\
\hline Intensif & $1,15 \mathrm{a}$ & $1,23 \mathrm{a}$ \\
Minimum & $1,11 \mathrm{ab}$ & $1,17 \mathrm{~b}$ \\
Tanpa Olah & $1,07 \mathrm{~b}$ & $1,09 \mathrm{c}$ \\
\hline BNT 0,05 & 0,05 & 0,04 \\
\hline
\end{tabular}

Keterangan: Dua nilai tengah yang diikuti oleh huruf dan kolom yang sama dinyatakan tidak berbeda nyata menurut uji BNT pada taraf 5\%

Tabel 3. Pengaruh pemupukan nitrogen jangka panjang terhadap kerapatan Isi pada kedalaman $0-20 \mathrm{~cm}$ dan $20-40 \mathrm{~cm}$ pada pertanaman padi gogo setelah panen.

\begin{tabular}{lcc}
\hline \multirow{2}{*}{ Pupuk Nitrogen $\left(\mathrm{kg} \mathrm{N} \mathrm{ha}^{-1}\right)$} & \multicolumn{2}{c}{ Kerapatan isi $\left(\mathrm{g} \mathrm{cc}^{-1}\right)$} \\
\cline { 2 - 3 } & Kedalaman $0-20 \mathrm{~cm}$ & Kedalaman $20-40 \mathrm{~cm}$ \\
\hline 0 & $1,13 \mathrm{a}$ & $1,20 \mathrm{a}$ \\
100 & $1,09 \mathrm{~b}$ & $1,13 \mathrm{~b}$ \\
\hline BNT 0,05 & 0,04 & 0,03 \\
\hline
\end{tabular}

Keterangan: Dua nilai tengah yang diikuti oleh huruf dan kolom yang sama dinyatakan tidak berbeda nyata menurut uji BNT pada taraf 5\% 
pada kedalaman $0-20 \mathrm{~cm}$ maupun kedalaman $20-40$ $\mathrm{cm}$ (Tabel 5). Pemupukan nitrogen jangka panjang dengan dosis $100 \mathrm{~kg} \mathrm{ha}^{-1}$ memiliki ruang pori totalyang lebih tinggi jika dibandingkan dengan tanpa pemupukan atau dosis pupuk $0 \mathrm{~kg} \mathrm{ha}^{-1}$ baik pada kedalam $0-20 \mathrm{~cm}$ maupun $20-40 \mathrm{~cm}$.

Kadar Air Tanah Kapasitas Lapang. Kadar air tanah padakapasitas lapang tidak dipengaruhi oleh pemupukan nitrogen jangka panjang dan sistem olah tanah baik pada kedalaman 0-20 cm maupun kedalaman 20 - $40 \mathrm{~cm}$ (Tabel 1). Sehingga tidak perlu dilakukan uji lanjut BNT taraf 5\%.

Kadar Air Tanah Titik Layu Permanen. Hasil penelitian menunjukkan bahwa kadar air tanah titik layu permanen dipengaruhi sistem olah tanah pada kedalaman $20-40 \mathrm{~cm}$ (Tabel 1). Tidak terjadi pengaruh sistem olah tanah terhadap kadar air tanah titik layu permanen pada kedalaman $0-20 \mathrm{~cm}$. Selain itu, tidak terdapat pengaruh pemupukan nitrogen jangka panjang terhadap kadar air tanah titik layu permanen kedalaman $0-20$ $\mathrm{cm}$ dan $20-40 \mathrm{~cm}$ serta tidak terjadi interaksi antara pupuk nitrogen jangka panjang dengan sistem olah tanah (Tabel 1).
Air tersedia. Air tersedia dipengaruhi sistem olah tanah pada kedalaman $20-40 \mathrm{~cm}$, tetapi tidak dipengaruhi oleh sistem olah tanah pada kedalaman 0 $20 \mathrm{~cm}$. Selain itu, tidak terdapat pengaruh pemupukan nitrogen jangka panjang terhadap air tersedia pada kedalaman 0 - $20 \mathrm{~cm}$ dan 20 - $40 \mathrm{~cm}$ serta tidak terjadi interaksi antara pupuk nitrogen jangka panjang dengan sistem olah tanah (Tabel 1).

C-Organik Tanah. Hasil analisis ragam menunjukkan bahwa sistem olah tanah dan pemupukan nitrogen berpengaruh nyata terhadap C-organik tanah sedangkan interaksinya tidak berpengaruh nyata (Tabel 1 ). Pada sistem olah tanah secara intensif memiliki nilai C-organik lebih rendah dibandingkan dengan sistem olah tanah minimum maupun tanpa olah tanah (Tabel 8). Pengaruh pemupukan nitrogen jangka panjang terhadap C-organik tanah pada pertanaman padi gogo (Tabel 9), dengan tanpa pemupukan $\mathrm{N}$ memiliki nilai C-organik lebih rendah dibandingkan dengan pemupukan pupuk nitrogen $100 \mathrm{~kg} \mathrm{~N} \mathrm{ha}{ }^{-1}$.

Tekstur Tanah. Hasil analisis laboratorium menunjukkan bahwa tekstur tanah pertanaman padi yang berada di Polinela memiliki tekstur tanah liat.

Tabel 4. Pengaruh sistem olah tanah jangka panjang terhadap terhadap Ruang Pori Total kedalaman $(0-20 \mathrm{~cm})$ pada pertanaman padi gogo setelah panen.

\begin{tabular}{lcc}
\hline \multirow{2}{*}{ Sistem Olah Tanah } & \multicolumn{2}{c}{ Ruang Pori Total $(\%)$} \\
\cline { 2 - 3 } & Kedalaman $0-20 \mathrm{~cm}$ & Kedalaman $20-40 \mathrm{~cm}$ \\
\hline Intensif & $56,81 \mathrm{~b}$ & $53,59 \mathrm{c}$ \\
Minimum & $58,32 \mathrm{ab}$ & $55,97 \mathrm{~b}$ \\
Tanpa Olah & $59,63 \mathrm{a}$ & $58,73 \mathrm{a}$ \\
\hline BNT 0,05 & 1,73 & 1,47 \\
\hline
\end{tabular}

Keterangan: Dua nilai tengah yang diikuti oleh huruf dan kolom yang sama dinyatakan tidak berbeda nyata menurut uji BNT pada taraf 5\%

Tabel 5. Pengaruh pemupukan nitrogen jangka panjang terhadap Ruang Pori Total kedalaman $(0-20 \mathrm{~cm})$ pada pertanaman padi gogo setelah panen

\begin{tabular}{lcc}
\hline \multirow{2}{*}{$\begin{array}{c}\text { Pupuk Nitrogen } \\
\left(\mathrm{kg} \mathrm{N} \mathrm{ha}^{-1}\right)\end{array}$} & \multicolumn{2}{c}{ Ruang Pori total (\%) } \\
\cline { 2 - 3 } 0 & $57,43 \mathrm{~b}$ & Kedalaman $20-40 \mathrm{~cm}$ \\
\hline 100 & $59,43 \mathrm{a}$ & $54,71 \mathrm{~b}$ \\
\hline BNT 0,05 & 1,41 & $57,50 \mathrm{a}$ \\
\hline
\end{tabular}

$\overline{\text { Keterangan: Dua nilai tengah yang diikuti oleh huruf dan kolom yang sama dinyatakan tidak }}$ berbeda nyata menurut uji BNT pada taraf 5\% 
Pembahasan. Hasil penelitian menunjukkan bahwa sistem olah tanah intensif memiliki rata - rata nilai kerapatan isi yang tinggi jika dibandingkan dengan sistem olah tanah lainnya pada kedalaman $0-20 \mathrm{~cm}$ dan kedalaman $20-40 \mathrm{~cm}$ (Tabel 2). Tingginya kerapatan isi pada pengolahan tanah intensif diduga karena proses olah tanah menyebabkan berkurangnya atau hilangnya kandungan bahan organik sehingga terjadi pemadatan tanah. Hal tersebut sesuai pernyataan Mauli (2008) bahwa pemadatan tanah dapat memampatkan fase padat tanah sehingga terjadi peningkatan kerapatanisi akibat kehilangan bahan organik saat pengolahan tanah secara intesif pada sistem pengolahan tanah konvensional. Selain itu, pengolahan tanah yang berlebihan mempunyai pengaruh buruk yaitu dapat menurunkan kandungan bahan organik tanah, menyebabkan hilangnya permukaan tanah yang dapat menimbulkan erosi, kekeringan tanah, dan agregasi tanah menurun (Utomo, 1997). Pada akhirnya, pengolahan tanah secara intensif akan menyebabkan kerapatan isi yang lebih tinggi jika dibandingkan dengan sistem olah tanah konservasi (sistem olah tanah minimum dan tanpa olah tanah) yang dapat mengganggu kesuburan tanah.Selainsistemolah tanah, pemupukan juga akan ikut memberi dampak terhadap kerapatan isi tanah. Kerapatan isi yang tergolong rendah baik pada kedalaman 0-20 dan 20-40 jika dibandingkan dengan dengan tanpa pemupukan diduga karena unsur $\mathrm{N}$ yang tergantung dalam residu pada pemupukan menyebabkan tanah menjadi gembur. Niswati, dkk. (1994) menyatakan bahwa pemupukan $\mathrm{N}$ yang dilakukan terus-menerus pada musim tanam sebelumnya dengan sistem olah tanah konservasi memiliki kandungan $\mathrm{N}$ tanah yang lebih tinggi dibandingkan dengan olah tanah intensif. Hal tersebut akan mengakibatkan tanah menjadi lebih gembur sehingga kerapatan isi akan menurun.

Meningkatnya kerapatan isi tanah akan mempengaruhi besarnya ruang pori total. Hasil penelitian menunjukkan bahwa sistem olah tanah intensif menghasilkan ruang pori total yang rendah jika dibandingkan dengan sistem olah tanah lainnya pada kedalaman $0-20 \mathrm{~cm}$ dan $20-40 \mathrm{~cm}$ (Tabel 4). Selain itu, pemupukan $100 \mathrm{~kg} \mathrm{~N}^{-1}$ pada kedalaman $0-20$ cm dan kedalaman $20-40 \mathrm{~cm}$ (Tabel 5) memiliki total

Tabel 6. Pengaruh sistem olah tanah jangka panjang terhadap terhadap titik layu permanen (\%) volumetrik kedalaman $(20-40 \mathrm{~cm})$ pada pertanaman padi gogo setelah panen.

\begin{tabular}{lcc}
\hline \multirow{2}{*}{ Sistem Olah Tanah } & \multicolumn{2}{c}{ Titik layu permanen $(\%)$} \\
\cline { 2 - 3 } & Kedalaman $0-20 \mathrm{~cm}$ & Kedalaman $20-40 \mathrm{~cm}$ \\
\hline Intensif & $13,25 \mathrm{a}$ & $22,88 \mathrm{a}$ \\
Minimum & $13,88 \mathrm{a}$ & $20,75 \mathrm{~b}$ \\
Tanpa Olah & $13,75 \mathrm{a}$ & $18,88 \mathrm{~b}$ \\
\hline BNT 0,05 & 1,53 & 2,03
\end{tabular}

Keterangan: Dua nilai tengah yang diikuti oleh huruf dan kolom yang sama dinyatakan tidak berbeda nyata menurut uji BNT pada taraf 5\%

Tabel 7. Pengaruh sistem olah tanah jangka panjang terhadap air tersedia (\%)volumetrik pada kedalaman $(20-40 \mathrm{~cm})$ pada pengamatan setelah panen di tanaman padi gogo.

\begin{tabular}{lcc}
\hline \multirow{2}{*}{ Sistem Olah Tanah } & \multicolumn{2}{c}{ Air tersedia (\%) } \\
\cline { 2 - 3 } & Kedalaman $0-20$ & Kedalaman $20-40 \mathrm{~cm}$ \\
\hline Intensif & $29,50 \mathrm{a}$ & $16,63 \mathrm{~b}$ \\
Minimum & $29,88 \mathrm{a}$ & $18,25 \mathrm{~b}$ \\
Tanpa Olah & $30,00 \mathrm{a}$ & $21,00 \mathrm{a}$ \\
\hline BNT 0,05 & 2,46 & 1,90 \\
\hline
\end{tabular}

Keterangan: Dua nilai tengah yang diikuti oleh huruf dan kolom yang sama dinyatakan tidak berbeda nyata menurut uji BNT pada taraf 5\% 
Tabel 8. Pengaruh sistem olah tanah jangka panjang terhadap terhadap C-organik Tanah (\%) pada pertanaman padi gogo

\begin{tabular}{lc}
\hline Sistem Olah Tanah & C-organik (\%) \\
\hline Intensif & $1,18 \mathrm{~b}$ \\
Minimum & $1,24 \mathrm{ab}$ \\
Tanpa Olah & $1,31 \mathrm{a}$ \\
\hline BNT 0,05 & 0,09 \\
\hline
\end{tabular}

Keterangan: Angka yang diikuti oleh huruf yang sama tidak berbeda nyata dengan uji BNT pada taraf 5\%

Tabel 9. Pengaruh pemupukan nitrogen jangka panjang terhadap C-organik tanah (\%) pada pertanaman padi gogo.

\begin{tabular}{ll}
\hline $\begin{array}{l}\text { Pupuk Nitrogen } \\
\left(\mathrm{kg} \mathrm{N} \mathrm{ha}^{-1}\right)\end{array}$ & C-organik (\%) \\
\hline 0 & $1,20 \mathrm{~b}$ \\
100 & $1,28 \mathrm{a}$ \\
\hline
\end{tabular}

\begin{tabular}{ll}
\hline BNT 0,05 & 0,07 \\
\hline
\end{tabular}

Keterangan: Angka yang diikuti oleh huruf yang sama tidak berbeda nyata dengan uji BNT pada taraf $5 \%$

ruang pori total yang tinggi. Besaran nilai ruang pori total akibat pemupukan dan rendahnya ruang pori total akibat olah tanah intensif diduga dipengaruhi dari dari kerapatan isi. Hal tersebut sesuai pernyataan Hanafiah (2004), kerapatan isiyang tinggi akan menimbulkan kepadatan tanah yang tinggi kemudian akan mengakibatkan ruang pori total mengecil. Madjid (2010) menyatakan bahwa kerapatan dari tiap - tiap partikel tanah akan mempengaruhi besarnya pori - pori didalam tanah baik pori mikro maupun pori makro. Selain itu, Elfiati dan Delvian (2010) yang menyatakan bahwa semakin tinggi kerapatanisi tanah maka semakin rendah total ruang porinya dan sebaliknya. Oleh sebab itu, nilai kerapatan isi dengan ruang pori total akan berlawanan sesuai dengan hasil penelitian yang telah didapatkan.

Pengukuran kadar air tanah kapasitas lapang penting untuk dilakukan. Hal tersebut akan berkaitan dengan kemampuan tanah atau media tanam dalam menjerap air yang nantinya akan dipergunakan tanaman dalam proses pertumbuhan dan perkembangan tanaman. Pemupukan nitrogen jangka panjang dan sistem olah tanah tidak memiliki pengaruh terhadap kapasitas lapang tanaman (Tabel 1). Meskipun telah memliki ruang pori yang lebih besar dengan pemupukan $100 \mathrm{~kg} \mathrm{~N} \mathrm{ha}^{-1}$ dan sistem olah tanah konservasi, belum menunjukkan hasil yang signifikan pada kadar air kapasitas lapang. Hasil yang didapat diduga karena selain dari faktor bahan organik yang didapat dari residu $\mathrm{N}$ pada proses pertanaman padi dan pengolahan tanah, kadar air tanah kapasitas lapang juga dipengaruhi oleh kemampuan tanaman dalam menyerap air yang tersedia. Hal tersebut sesuai pernyataan Hakim, dkk. (1986). Selain sifat tanah, faktor tumbuhan juga sangat mempengaruhi jumlah air yang dapat diabsorbsi tumbuhan dari tanah. Oleh sebab itu, baik sistem olah tanah maupun pemberian pupuk $\mathrm{N}$ jangka panjang belum mampu meningkatkan hasil yang baik terhadap kadar air kapasitas lapang.

Selain kadar air kapasitas lapang, terdapat kadar air tanah padatitik layu permanen yang di pengaruhi oleh pemupukan nitrogen jangka panjang serta sistem olah tanah. Hasil menunjukkan bahwa tidak terdapat pengaruh pemupukan nitrogen jangka panjang terhadap kadar air tanah titik layu permanen baik pada kedalaman $0-20 \mathrm{~cm}$ maupunkedalaman $20-40 \mathrm{~cm}$. Hal tersebut diduga karena faktor tanaman dalam menggunakan atau kebutuhan tanaman akan air tidak berbeda antara tanaman yang satu dan yang lainnya, sehingga tidak terjadi perbedaan kadar air tanah titik layu permanen. Oleh sebab itu, tidak terjadi perbedaan kadar air tanah titik layu permanen pada sampel yang diambil.

Perbedaan pengaruh terjadi pada kadar air tanah titik layu permanen pada kedalaman $20-40 \mathrm{~cm}$ (Tabel 6). Pada kedalaman $0-20 \mathrm{~cm}$ tidak terjadi pengaruh sistem olah tanah terhadap kadar air tanah titik layu permanen. Akan tetapi, pada kedalaman $20-40 \mathrm{~cm}$ terdapat pengaruh sistem olah tanah terhadap kadar air tanah titik layu permanen. Hal tersebut diduga karena pada lapisan atas $0-20 \mathrm{~cm}$ masih banyak mengandung humus yang dapat digunakan tanah untuk penahan air, sedangkan pada kedalam $20-40 \mathrm{~cm}$ memiliki kandungan yang lebih sedikit. Perbedaan tersebut sesuai dengan pernyataan Hardjowigono (1992), semakin ke bawah lapisan tanah akan semakin menurun kandungan bahan organik atau humus yang terdapat pada lapisan tanah.

Perbedaan kandungan bahan organik tersebut menyebabkan perbedaan pengaruh yang timbul pada sistem pengolahan tanah terhadap kadar air tanah titik layu permanen. Pengolahan tanah secara intensif pada kedalaman $20-40 \mathrm{~cm}$ telah menyebabkan pori tanah lebih kecil dibandingkan olah tanah konservasi sebagai akibat dari semakin berkurangnya kandungan bahan organik tanah. Pada akhirnya kondisi tersebut akan mempengaruhi kadar air tanah titik layu permanen. Oleh 
sebab itu perbedaan kadar air tanah titik layu permanen terjadi pada lapisan $20-40 \mathrm{~cm}$.

Hasil penelitian menunjukkan bahwa terjadi perbedaan air tersedia karena pengaruh sistem olah tanah pada kedalaman $20-40 \mathrm{~cm}$. Sistem olah tanah intesif memiliki nilai air tersedia yang lebih rendah dibandingkan dengan perlakuan sistem olah tanah lainnya. Kadar air yang rendah diduga karena penurunan ruang pori total yang mampu untuk menyerap air sehingga air tersedia menjadi rendah. Dao (1993)melaporkanbahwa, sistem olah tanah konservasi dapat meningkatkan kadar air tanah bila dibandingkan dengan olah tanah intensif. Pengurangan olah tanah dapat dilakukan untuk menghindari terjadinya kembali kepadatan tanah setelah diolah dan dapat digunakan teknik pemberian bahan organik ke dalam tanah. Oleh sebab itu, olah tanah konservasi dapat menjadi pilihan dalam meningkatkan air tanah tersedia.

Hasil analisis ragam yang menunjukkan bahwa sistem olah tanah dan pemupukan nitrogen berpengaruh nyata namun interaksinya tidak nyata terhadap C-organik tanah (Tabel 8). Pada sistem tanpa olah tanah kadar Corganik tanah (Tabel 8) lebih besar dibandingkan olah tanah intensif. Hal tersebut disebabkan tanpa olah tanah mengandung serasah, sedangkan olah tanah intensif tidak. Lebih tingginya BOT karena pemberian pupuk nitrogen sebagai sumber energi yang dapat meningkatkan aktivitas mikroorganisme tanah, sehingga dekomposisi bahan organik (serasah) dan mineralisasi unsur hara dapat berjalan dengan cepat dan unsur hara dapat diserap oleh tanaman. Hal ini sesuai dengan pendapat Hanafiah, dkk., (2009), yang menyatakan bahwa kecepatan dekomposisi bahan organik oleh mikroba perombak tanah dipengaruhi ketersedian nitrogen, sebab kecepatan dekomposisi bahan organik sebanding dengan nitrogen yang ditambahkan ke dalam tanah.

Pada hasil analisis tekstur tanah menunjukkanbahwa tanah yang berada di area petanaman padi memiliki fraksi tanah liat untuk semua perlakuan Tanah liat memiliki permukaan yang lebih halus dibandingkan dengan tanah yang berdominan pasir.

Secara garis besar, hasil penelitian menunjukkan bahwa C-organikmempengaruhikerapatanisi, ruangpori total, air tersediadanjugatitiklayu permanent. C- organik yang tinggidapatmenurunkankerapatanisidantitiklayu permanent sehinggamemperbesarruangpori total dan air tersediadalamtanah. sistem tanpa olah tanahdan olah tanah minimum menjadi alternatif yang baik dalam budidaya tanaman.Selain itu, dengan penggunaan pupuk nitrogen jangka panjang juga dapat menjadi solusi untuk tetap dapat mempertahankan fungsi tanah agar tetap terjaga dengan baik dan sehat. Oleh sebab itu, olah tanah konservasi dan pemupukan $\mathrm{N}$ jangka panjang menjadi solusi dalam proses budidaya yang baik dan berkelanjutan.

\section{KESIMPULAN}

Berdasarkanhasil penelitian yang telah dilakukan, maka diperoleh kesimpulan bahwa Sistem tanpa olah tanah mampu meningkatkan porositas tanah, C-organik tanah dan air tersedia, serta menurunkan kerapatan isi dan titik layu permanen. Pemupukan $\mathrm{N}$ jangka panjang mampu menurunkan kerapatan isi, meningkatkan ruang pori total, dan C-organik tetapi belum mampu untuk meningkatkan air tersedia dalam tanah. Tidak terjadi interaksi antara sistem olah tanah dengan pemupukan $\mathrm{N}$ jangka panjang terhadap air tanah tersedia.

\section{DAFTAR PUSTAKA}

Afandi. 2005. Penuntun Praktikum Fisika Tanah. Universitas Lampung. Bandar Lampung.

Elfiati, D dan Delvian. 2010. Laju Infiltrasi pada Berbagai Tipe Kelerengan di Bawah Tegakan Ekaliptus di Areal HPHTI PT. Toba Pulp Lestari Sektor Aek Nauli. Universitas Sumatera Utara. Medan.

Hakim, N., M.Y. Nyapka, A.M. Lubis, S.G. Nugroho, R. Saul, A. Diha, G.B. Hong, dan H.H Bailey. 1986. Dasar-Dasar Ilmu Tanah. Universitas Lampung. Bandar Lampung. $448 \mathrm{hlm}$.

Hanafiah, K. A. 2004. Dasar-Dasar Ilmu Tanah. PT. Raja Grafindo Persada. Jakarta.

Hardjowijono, S. 1992. Ilmu Tanah. PT Mediyatama Sarana Perkasa. Jakarta.

Madjid. 2010. Sifat dan Ciri Tanah. Fakultas Pertanian Institut Pertanian Bogor. Bogor.

Mauli, R.L. 2008. Kajian Sifat Fisika dan Kimia Tanah Akibat Sistem Rotasi Penggunaan Lahan Tembakau Deli. Universitas Sumatera Utara, Medan.

Niswati, A., M.Utomo, dan S.G. Nugroho. 1994. Dampak Mikrobiologi Tanah Penerapan Teknik Tanpa Olah Tanah dengan Herbisida Amino Glifosfat Secara Terus-menerus pada Lahan Kering di Lampung. Laporan Penelitian DP3M. Unila. 
Pulung, M. A. 2005. Kesuburan Tanah. Universitas Lampung. Bandar Lampung. 287 hlm. (Buku Ajar).

Utomo, M. Olah Tanah Konservasi Teknologi Pengolahan Lahan Kering Berkelanjutan. Pidato Pengukuhan Guru Besar Ilmu Pengelolaan Tanah Fakultas Pertanian Universitas Lampung. 22 September 1997. $26 \mathrm{hlm}$. 